\title{
Costs and effects of paliperidone extended release compared with alternative oral antipsychotic agents in patients with schizophrenia in Greece: a cost effectiveness study
} Maria Geitona ${ }^{1}$, Hara Kousoulakou ${ }^{2}$, Markos Ollandezos $^{3}$,
Kostas Athanasakis $^{3}$, Sotiria Papanicolaou*4 ${ }^{*}$ and Ioannis Kyriopoulos

Address: ${ }^{1}$ Department of Economics, University of Thessaly, Magnissias 96, Dionyssos 14576, Greece, ${ }^{2}$ Institute for Economic and Industrial Research, Tsami Karatasi 11, 11742 Athens, Greece, ${ }^{3}$ Department of Health Economics, National School of Public Health, Aleksandra's Avenue 196, 11521 Athens, Greece and "Janssen-Cilag Pharmaceutical SACI, Eirinis Avenue 56, 15121 Pefki, Athens, Greece

Email: Maria Geitona - geitona@econ.uth.gr; Hara Kousoulakou - kousoul@iobe.gr; Markos Ollandezos - markolan@gmail.com; Kostas Athanasakis - k.athanasakis@gmail.com; Sotiria Papanicolaou* - spapanic@jacgr.jnj.com; Ioannis Kyriopoulos - nsph-

kyr@ath.forthnet.gr

* Corresponding author

Published: 18 June 2009

Annals of General Psychiatry 2009, 8:15 doi:10.1186/1744-859X-8-15
Received: 17 June 2009

Accepted: 18 June 2009

This article is available from: http://www.annals-general-psychiatry.com/content/8/1/15

(c) 2009 Geitona et al; licensee BioMed Central Ltd.

This is an Open Access article distributed under the terms of the Creative Commons Attribution License (http://creativecommons.org/licenses/by/2.0), which permits unrestricted use, distribution, and reproduction in any medium, provided the original work is properly cited.

\begin{abstract}
Correction to Geitona M, Kousoulakou H, Ollandezos M, Athanasakis K, Papanicolaou S and Kyriopoulos I: Costs and effects of paliperidone extended release compared with alternative oral antipsychotic agents in patients with schizophrenia in Greece: a cost effectiveness study. Annals of General Psychiatry 2008, 7:16. This correction reports changes in the values listed for Ziprasidone and Aripiprazole in Table Ten.
\end{abstract}


Table I: Mean annual number of stable days and cost per patient by pharmaceutical treatment.

\begin{tabular}{|c|c|c|c|c|c|c|}
\hline & Paliperidone ER & Olanzapine & Risperidone & Quetiapine & Ziprasidone & Aripiprazole \\
\hline \multicolumn{7}{|l|}{ Base case: } \\
\hline Cost $(€)$ & 7.030 & 7.034 & 7.082 & 8.321 & 7.807 & 7.713 \\
\hline Effectiveness & 272.5 & 272.2 & 265.5 & 260.7 & 258.6 & 260.5 \\
\hline \multicolumn{7}{|c|}{ Incremental cost and effectiveness compared with paliperidone ER: } \\
\hline Cost $(€)$ & - & 4 & 52 & 1.291 & 777 & 683 \\
\hline Effectiveness & - & -0.3 & -7.0 & -11.8 & -13.9 & -12.0 \\
\hline
\end{tabular}

\section{Correction}

Following the publication of our article [1], it has come to our attention that there was an error with the values listed for Ziprasidone and Aripiprazole in Table Ten. Table Ten should therefore appear as shown in this correction (Table $1)$.

\section{References}

I. Geitona M, Kousoulakou H, Ollandezos M, Athanasakis K, Papanicolaou S, Kyriopoulos I: Costs and effects of paliperidone extended release compared with alternative oral antipsychotic agents in patients with schizophrenia in Greece: a cost effectiveness study. Annals of General Psychiatry 2008, 7:I6.

Publish with Biomed Central and every scientist can read your work free of charge

"BioMed Central will be the most significant development for disseminating the results of biomedical research in our lifetime. "

Sir Paul Nurse, Cancer Research UK

Your research papers will be:

- available free of charge to the entire biomedical community

- peer reviewed and published immediately upon acceptance

- cited in PubMed and archived on PubMed Central

- yours - you keep the copyright

Submit your manuscript here:

http://www.biomedcentral.com/info/publishing_adv.asp 